\title{
The effect of mangrove restoration on avian assemblages of a coastal lagoon in southern Mexico
}

\author{
Julio Cesar Canales-Delgadillo ${ }^{1}$, Rosela Perez-Ceballos ${ }^{\text {Corresp., } 1}{ }^{1}$, Mario Arturo Zaldivar-Jimenez ${ }^{2}$, Martin Merino- \\ Ibarra $^{3}$, Gabriela Cardoza ${ }^{4}$, Jose-Gilberto Cardoso-Mohedano ${ }^{1}$ \\ 1 Instituto de Ciencias del Mar y Limnología, Universidad Nacional Autónoma de México, Ciudad del Carmen, Campeche, México \\ 2 ATEC Asesoría Técnica y Estudios Costeros SCP, Mérida, Yucatán, México \\ 3 Instituto de Ciencias del Mar y Limnología, Universidad Nacional Autónoma de México, Ciudad de México, México \\ 4 Centro de Investigación de Ciencias Ambientales, Universidad Autónoma del Carmen, Ciudad del Carmen, Campeche, México \\ Corresponding Author: Rosela Perez-Ceballos \\ Email address: ryperezce@conacyt.mx
}

Background. Mangrove forests provide many ecosystem services, including the provision of habitat that supports avian biodiversity. However, hurricanes can knock down trees, alter hydrologic connectivity, and affect avian habitat. In 1995, Hurricanes Opal and Roxanne destroyed approximately 1,700 ha of mangrove forest in Laguna de Términos, Mexico. Since then, hydrological restoration has been implemented to protect the mangrove forest and its biodiversity. Methods. Since avian communities are often considered biological indicators of ecosystem quality, avian diversity and species relative abundance were evaluated as indicators of mangrove restoration success by comparing undisturbed mangrove patches with those affected by the hurricanes. Using bird surveys, similarity analyses, and generalized linear models, we evaluated the effects of water quality variables and forest structure on the relative abundance and diversity of the avian community in disturbed, restored, and undisturbed mangrove patches. Results. Higher bird species richness and relative abundances were found in disturbed and restored sites compared to the undisturbed site. After restoration, values of frequency of flooding, water temperature, tree density, and the number of tree species were more similar to that of the undisturbed site than to the values of the disturbed one. Such variables influenced the relative abundance of bird guilds in the different habitat conditions. Furthermore, some insectivorous bird species, such as the Yellow Warbler and Tropical Kingbird, were found to be similarly abundant in both undisturbed and restored sites, but absent or very low in occurrence at the disturbed site. Conclusions. Collectively, our results strongly suggest that hydrologic restoration helps to enhance niche availability for different bird guilds, including water and canopy bird species. Our work can help inform management strategies that benefit avian communities in mangrove forests and wetland systems. 
1 The effect of mangrove restoration on avian assemblages of a coastal lagoon in southern 2 Mexico

3

4 Julio Cesar Canales-Delgadillo ${ }^{1}$, Rosela Pérez-Ceballos ${ }^{1}$, Mario Arturo Zaldivar-Jimenez ${ }^{2}$, 5 Martin Merino-Ibarra ${ }^{3}$, Gabriela Cardoza Cota ${ }^{4}$, Jose Gilberto Cardoso-Mohedano ${ }^{1}$.

6

$7 \quad{ }^{1}$ Instituto de Ciencias del Mar y Limnología, Universidad Nacional Autónoma de México.

8 Ciudad del Carmen, Campeche. México.

$9 \quad{ }^{2}$ ATEC Asesoría Técnica y Estudios Costeros SCP. Mérida, Yucatán, México.

$10 \quad{ }^{31}$ Instituto de Ciencias del Mar y Limnología, Ciudad de México, México.

$11{ }^{4}$ Centro de Investigación de Ciencias Ambientales, Universidad Autónoma del Carmen, Ciudad 12 del Carmen, Campeche, México.

13 Corresponding Author:

14 Rosela Pérez-Ceballos ${ }^{1}$ Instituto de Ciencias del Mar y Limnología UNAM. Km 9.5Carretera Carmen-Puerto Real. Ciudad del Carmen, Campeche. C. P. 24157. México.

17 Email address: rosela.perezc@gmail.com

\section{Abstract}

Background. Mangrove forests provide many ecosystem services, including the provision of habitat that supports avian biodiversity. However, hurricanes can knock down trees, alter hydrologic connectivity, and affect avian habitat. In 1995, Hurricanes Opal and Roxanne destroyed approximately 1,700 ha of mangrove forest in Laguna de Términos, Mexico. Since then, hydrological restoration has been implemented to protect the mangrove forest and its biodiversity.

Methods. Since avian communities are often considered biological indicators of ecosystem quality, avian diversity and species abundance were evaluated as indicators of mangrove restoration success by comparing undisturbed mangrove patches with those affected by the hurricanes. Using bird surveys, similarity analyses, and generalized linear models, we evaluated the effects of water quality variables and forest structure on the abundance and diversity of the avian community in disturbed, restored, and undisturbed mangrove patches. 
32 Results. Higher bird species richness and abundances were found in disturbed and restored sites 33 compared to the undisturbed site. At the restored site, frequency of flooding, water temperature,

34

35

36 37 38 tree density, and the number of tree species were, more similar to the undisturbed site than to the disturbed site. Such variables influenced the abundance of bird guilds in the different habitat conditions. Furthermore, some insectivorous bird species, such as the Yellow Warbler and Tropical Kingbird, were found to be similarly abundant in both undisturbed and restored sites, but absent or very low in occurrence at the disturbed site.

Conclusions. Collectively, our results strongly suggest that hydrologic restoration helps to enhance niche availability for different bird guilds, including water and canopy bird species. Our work can help inform management strategies that benefit avian communities in mangrove forests and wetland systems.

\section{Introduction}

Mangrove forests provide valuable ecosystem services. These highly productive ecosystems can prevent erosion, trap sediments, and provide wind protection for coastal communities (WarrenRhodes et al., 2011). Mangrove forests also support important nursery habitats for a variety of organisms including pelagic and marine vertebrates and invertebrates, mammals, and birds (Nagelkerken et al., 2008; Lee et al., 2014; Serafy et al. 2015). In Mexico, mangroves provide important habitats for specialist species such as the Mangrove Cuckoo (Coccizus minor), the Mangrove Finch (Camarhynchus heliobates), the Mangrove Hummingbird (Amazilia buocardi), and the Mangrove Warbler (Setophaga petechia bryanti) (Polidoro et al., 2010; Andrade et al., 2012; Gardner et al., 2012; Buelow \& Sheaves, 2015). Mangrove forests can also improve water quality (Wang et al., 2010), and provide economically important products. Nevertheless, it is estimated that about $35 \%$ of the global mangrove cover has been lost, mainly due to forest clearance for fish farming, urbanization, habitat fragmentation, and fuel and timber production (Valiela, Bowen \& York, 2001; Alongi, 2008; Donato et al., 2011).

In Mexico, four mangrove species are distributed along the Gulf of Mexico coast: red (Rhizophora mangle), black (Avicennia germinans), white (Laguncularia racemosa), and button (Conocarpus erectus) mangroves, covering approximately 742,000 hectares (ha) (Giri et al., 2011). The estimated value of mangroves due to fisheries, carbon sequestration, forestry coastal protection, erosion control, water treatment and other environmental, recreational and traditional 
63 uses is about $\$ 80,000$ to $\$ 194,000$ USD per ha ${ }^{-1} \mathrm{yr}^{-1}$ (Salem \& Mercer, 2012; Costanza et al.,

64 2014). Such a value represents up to a total of \$59-143 billion USD for the Mexican mangroves.

65 Globally, Mexico ranks fourth in terms of total mangrove area (Giri et al., 2011); however, as in

66 other parts of the world, the rate of degradation of mangrove forests in Mexico has been high in

67 the past century. Mangrove cover has been reduced by approximately $10 \%$ of the original area in

68 the last 40 years, and about $2 \%(15,000 \mathrm{ha})$ of the area that remains has been classified as

69 disturbed (Valderrama et al., 2014). In most mangrove forests, there has

70 been a loss of connectivity and a decrease in heterogeneity, which has reduced faunal diversity,

71 including avian populations (Mohd-Azlan, Noske \& Lawes, 2015; Hauser et al., 2017; Amir,

72 2018).

73 Because restoration can help mitigate climate change effects and the consequential biodiversity

74 loss (Nilsson \& Aradottir, 2013), interest in the ecological restoration of coastal wetlands is

75 currently growing (Palmer, Hondula \& Koch, 2014; Suding et al., 2015). The disturbance of

76 coastal wetlands is often accompanied by changes in hydrological patterns, including the

77 hydroperiod, which is defined as the amount of time, the frequency, and the level with which a

78 wetland is covered by water, a key factor determining success in wetland restoration (Turner \&

79 Lewis, 1996; Zaldívar-Jiménez et al., 2010; Wortley, Hero \& Howes, 2013). For instance,

80 sediment deposition in the tidal channels affects the amount of time and the frequency at which a

81 mangrove is flooded (Woodroffe et al., 2016). These kinds of changes affect the water quality

82 and the composition of plant and animal communities (Schaffelke, Mellors \& Duke, 2005;

83 Krauss et al., 2006; Crase et al., 2013). Hence, the success of ecological restoration can be

84 assessed through a system of indicators that generate information about the recovery of wetland

85 functions. Such a system might include landscape features, biogeochemical processes (Cvetkovic

86 \& Chow-Fraser, 2011; Zhang et al., 2012), ecosystem services, and the composition of biological

87 assemblages (e.g., vegetation, crustaceans, mollusk, and vertebrates) (Thornton \& Johnstone,

88 2015; Salmo, Tibbetts \& Duke, 2016). Therefore, species richness, abundance, and community

89 structure can be used to evaluate the biological outcomes of restoration efforts (Zhao et al.,

90 2016).

91 Because of their diverse roles within the trophic webs, bird communities are key elements for

92 describing the energetics of ecosystems (Wenny et al., 2011; Adame et al., 2015; McFadden,

93 Kauffman \& Bhomia, 2016), and are considered useful indicators of ecosystem health 
94 (Canterbury et al., 2000; Bryce, Hughes \& Kaufmann, 2002; Catterall et al., 2012). For instance, 95 monitoring of pollutants such as DDT and organochlorines, and the effects of variations in 96 hydroperiod in the Everglades were carried out using water and wading bird species (Frederick et 97 al., 2009; Lavoie et al., 2010; Lantz, Gawlik \& Cook, 2011; Boyle, Dorn \& Cook, 2012).

98 Moreover, bird diversity has been used as an indicator of temporal changes in mangrove health 99 (Behrouzi-Rad, 2014), and to assess the impacts of climate change and coastal development 100 (Ogden et al., 2014). While avian community monitoring can be a useful tool for evaluating the 101 health of wetland ecosystems, its use for assessment of ecological restoration has been rarely 102 employed (Weller, 1995; Cui et al., 2009; Gyurácz, Bánhidi \& Csuka, 2011; Li et al., 2011;

103 Catterall et al., 2012; Zou et al., 2014).

104 Laguna de Términos is a coastal lagoon located in Mexico along the southwestern coast of the 105 Gulf of Mexico. It is the second biggest coastal lagoon in Mexico, supporting approximately 106259,000 ha of mangrove forest (33\% of all mangrove forest in Mexico) and 262 bird species, 107 among other vertebrate taxa (Villalobos-Zapata \& Mendoza-Vega, 2010). As a result, Laguna de 108 Términos has been recognized as a Ramsar wetland of international importance (Chape, 109 Spalding \& Jenkinst, 2008). However, due to fisheries, oil-extraction activities, illegal timber 110 exploitation, and urbanization, nearly $26 \%$ of the mangrove habitat in this lagoon is considered 111 degraded (Zaldívar-Jiménez et al., 2017). Additionally, in 1995, the lagoon was affected by 112 Hurricanes Opal (category 4) and Roxana (category 3), which destroyed 1,700 ha of mangrove 113 (Pérez-Ceballos et al., 2013). Fallen trees blocked some creeks (hereafter tidal channels), mainly 114 the secondary ones. The silting of channels altered the hydroperiod patterns and biogeochemical conditions, leading to the mortality of adult trees and inhibiting the natural regeneration of the mangrove. Moreover, this condition has led to a constantly increasing area of dead trees around

117 the points affected by the hurricanes. In order to increase the resilience of these mangrove 118 forests, protect their biological diversity, educate others, and contribute to the sustainable 119 development of the adjacent local communities, from October 2010 to November 2012, restoration activities were implemented. In brief, restoration activities included an environmental and social diagnosis, as well as the formulation of a management plan before the restoration

122 implementation. The primary restoration activity was the desilting and unblocking of the main 123 and secondary tidal channels. Where needed, new secondary channels were dug based on the 
124 microtopography analysis of each site selected for restoration. Desilting, unblocking, and

125 channel digging were carried out by local women and men only by hand.

126 The objective of this study was to use the changes on the avian abundance and diversity as

127 indicators of the restoration success of a mangrove site. We specifically asked: 1) whether the

128 avian community structure differs between not obviously affected mangrove patches and those

129 affected by the hurricanes; 2) whether hydroperiod and water quality influence the diversity or

130 the abundance of birds; and 3) which species could be used as indicator species of post-

131 restoration recovery? The sampling was carried out on a landscape mosaic with different strata:

132 undisturbed patches, patches without restoration, and patches three years after restoration. The

133 water quality variation among the study sites, along with the avian community diversity and

134 abundance of species, were evaluated as indicators of mangrove restoration success.

135

136 Materials \& Methods

\section{Study area}

138 Laguna de Términos is a coastal wetland located in Campeche, Mexico. It covers about $150 \mathrm{~km}^{2}$

139 and is connected to the Gulf of Mexico by two inlets at the east and west sides of Isla del

140 Carmen, a calcareous sandbar that supports 5,900 ha of mangrove, of which around $26 \%$ are

141 disturbed. The annual average rainfall and temperature are approximately $1,420 \mathrm{~mm}$ and $27^{\circ} \mathrm{C}$

142 respectively (David \& Kjerfve, 1998). The study area is an estuary known as Bahamitas, located

143 on the east of Isla del Carmen (637787.52E, 2066226.35N, and 633872.60E, 2064181.96N UTM

144 Q15, Fig. 1). The hydrological restoration was implemented from October 2010 to November

1452012 through desilting and unblocking of natural tidal channels. Where needed, new secondary

146 channels were created to induce natural regeneration of the vegetation, and to enhance the water

147 quality (oxygenation and salinity) of 1,300 ha of disturbed mangrove through water exchange

148 (Zaldívar-Jiménez et al., 2017). The creation of new tidal channels relied on the modeling of

149 hydrological flow-paths after analysis of a digital elevation model created from the obtained

150 microtopography data. All the work was undertaken by hand using shovels, and involved local

151 inhabitants (10 people ha ${ }^{-1}$ ), who were trained through workshops on habitat restoration and

152 environmental education, as well as being advised on social and community organization for

153 sustainable development through bird watching and catch-and-release fishing (Zaldívar-Jiménez

154 et al., 2017). 


\section{Sampling sites and forest structure}

157 Based on the digital analysis of a Worldview 2013 image and subsequent field surveys, three

158 different patches for sampling were identified and selected according to their condition of

159 degradation: i) First were undisturbed sites with well-established adult trees and no significant

160 human activities. Here, at least $80 \%$ of the trees were alive and there was no evident alteration of

161 the hydrological connectivity due to the effects of hurricanes. ii) Second were disturbed sites

162 with all the trees dead, except for some few individuals at the edges, and no seedling

163 establishment or with no more than $10 \%$ of scrub mangroves alive. iii) Third were restored sites

164 that showed similar conditions to the degraded site prior to restoration activities implemented

165 during 2010 and 2012 to allow water to flow in and out through the topography of the wetland.

166 After restoration (three years), this site already showed the establishment of seedlings and some

167 saplings, and no more than $50 \%$ of the scrub mangroves were dead.

168 For each sampling site, two $10 \mathrm{~m}$ x $10 \mathrm{~m}$ random sampling plots were surveyed to determine the

169 forest structure and the number of live trees. On the same plots, measures of diameter at breast

170 height $(\mathrm{DBH})$, canopy height, and basal area were collected to determine the forest cover. Tree

171 density was estimated by counts of all trees with $\mathrm{DBH}>2.5 \mathrm{~cm}$ (Schaeffer-Novelli, Vale \&

172 Cintrón, 2015). These data were used to investigate the effects of the vegetation structure on bird

173 abundance in each sampling site (McElhinny et al., 2005; Azhar et al., 2013).

\section{Hydrologic and water quality parameters}

176 To assess the relationship of bird abundance with the water quality parameters, 11 sampling

177 points were established every $100 \mathrm{~m}$ within each survey site to measure the water depth, as well

178 as the temperature and salinity of surficial water of the tidal channels. Water depth was measured

179 using a ruler at the center of the tidal channels. Temperature and salinity were recorded using a

180 parametric probe, YSI-30 (YSI Incorporated, USA). The $\mathrm{pH}$ and oxidation reduction potential

181 (ORP) were recorded using a portable tester, HI916 (Hanna Instruments, Inc., USA). All these

182 data were recorded twice monthly. The hydroperiod patterns among the sampling sites were also

183 compared by contrasting the tidal range (the level of the flooding in $\mathrm{cm}$ ), the flooding duration

184 (the time in hours that a site stand flooded), and the flooding frequency (the number of times per 
185 month that a place floods). These measures were recorded during the entire sampling period 186 every 60 minutes using a HOBO U20-001-01-Ti logger placed at each sampling site.

\section{Birds survey}

To estimate species richness and abundance, monthly bird surveys (December 2014 to June 2015 ) were conducted by boat. This period of time was selected because it allows finding both

191

192

193

194

195

196

197

198

199

200

201

202

203

204

205

206

207

208

209

210

211

212

213

214

215 migrant birds in winter and residents species in spring and early summer. Counting points $(\mathrm{n}=$ 11 for each sampling site) were used to record bird species and count individuals per species within each sampling site. We carried out a systematic sampling with a randomly selected start point at each sampling area. Then, the next ten counting points were separated $100 \mathrm{~m}$ from each other. Because a count at a particular point can be affected by whether the neighboring points are above or below their averages (Pendleton, 1995), we tested for independence of our counting points through a Pearson's test of conditional independence. Additionally, we used the function Moran included in the R package ape (Paradis, Claude \& Strimmer, 2004) to treat the abundance data across counting points with a Moran's index test to ensure that they were not spatially biased. As recommended for field methods in bird surveys (Gregory, Gibbons \& Donald, 2004), we used a minimum of four visits to each counting point (four in winter and four in spring). To avoid double count, a single observer counted individual birds at standard intervals of time (10 min). To help deal with varying detectability of different species, observations were made for two consecutive days (Bibby et al., 1992; Gregory, Gibbons \& Donald, 2004; Schmidt, McIntyre \& MacCluskie, 2013). To deal with species mimicry, besides song and call recognition, birds were identified by a trained observer that sought field marks using $10 \times 42$ binoculars. We recorded all species and individuals seen or heard within the first $20 \mathrm{~m}$ radius at each counting point. All species and individuals observed on the vegetation, water, or flying within the observation radius (up to $15 \mathrm{~m}$ above) were counted. We did not account for passing or transient birds flying on the sampling areas that did not stop there to feed or rest. The sampling effort was equivalent to approximately 77 hours of surveying over the three sampling sites. All bird species observed outside the sampling radius were also recorded but not included in further analyses of species abundance. The reliability of our sampling design concerning species detectability, temporal, and size representativeness was assessed by the implementation of an evaluation framework for ecological research (Battisti, Dodaro \& Franco, 2014). 


\section{Statistical analyses}

218 The data on hydroperiod and environmental variables were explored for normality through

219 Shapiro-Wilk tests, which are ratios of two estimates of the variance in a normal distribution 220 calculated from a set of observations (Royston, 1995). Data that met the assumptions of 221 normality and independence were analyzed using a one-way analysis of variance (ANOVA) to

222 compare the means between the data from all sampling sites. When significant differences were 223 found, ANOVA results were further examined through an honestly-significant-difference 224 Tukey's test, a multiple comparisons procedure to find the differences between all levels of a 225 factor once the hypothesis of equality from the ANOVA test is rejected. When the data did not 226 meet the assumption of normality, we used Kruskal-Wallis one-way analysis of variance by 227 ranks, a non-parametric alternative to ANOVA for multiple comparisons. To contrast the levels 228 of a factor from this analysis, we used the function posthoc.kruskal.nemenyi.test from the $\mathrm{R}$ 229 package PMCMR, a post-hoc alternative to performing multiple comparisons for non230 parametrics (Pohlert, 2014).

231 Species richness and abundance for each sampling site were calculated based on the number of 232 recorded individuals per species. Diversity was estimated using the inverse of Simpson's Index $233\left(1 \Sigma(n / N)^{2}\right)$ which indicates greater diversity as the resulting value approaches 1, while the 234 dominance (the extent to which a taxon is more numerous than others) was assessed through the 235 Berger-Parker Index $\left(d=N_{\max } / N_{T}\right)$, in which the lower the value of $\mathrm{d}$ results in a more even 236 dominance in the sample (for details on the formulae see Ingram (2008)). To reduce biases 237 caused by non-detected species, the expected species richness was calculated using the Jack1 238 estimator, which is adequate to estimate actual species richness when the number of sampling 239 units is small (<20 samples or individuals) or when the samples are not the same size. It uses the 240 total number of observed species in a set of samples, the total number of unique species in each 241 sample, and the number of samples for the calculations (Smith \& van Belle, 1984; Gotelli \& 242 Colwell, 2011). Abundance and evenness (how equal the bird community is numerically) among 243 sampling sites were compared through rank-abundance curves. The curves were constructed as 244 implemented in the R package BiodiversityR (Kindt \& Coe, 2005). From the pooled data, the 245 total number of individuals was calculated to obtain their abundance (y-axis) and then ranked 246 from the most to the least abundant species ( $\mathrm{x}$-axis). Then, the same procedure was implemented 
247 for each sampling location (Kindt \& Coe, 2005). Key bird species to particular sampling sites 248 were identified on the basis of their abundance through a one-way Simper test carried out in 249 PRIMER 7 (Anderson, Gorley \& Clarke, 2008). The Simper test estimated the contribution of 250 each species abundance to the total dissimilarity among the sampling sites using Bray-Curtis 251 distances, which helps find discriminating features within habitats that explain differences in 252 community composition (Clarke, 1993). Additionally, we estimated the indicator species index

253

254 255

256

257 258

259

260

261

262

263

264

265

266

267

268

269

270

271

272

273

274

275

276

277 value (IndVal) to find the value of particular species to each sampling site as indicators of their condition. The IndVal uses both the relative abundance (instead of the absolute abundance), and the relative frequency of each species to estimate its value as a percentage (Roberts, 2016). We also investigated the relationship between species abundance and environmental variables by means of redundancy (RDA) and multivariate analyses through generalized linear models (glms). The RDA was selected because there was a linear response of the abundance of birds to the measured environmental variables. For both the RDA and the glms, the birds' abundances were used as the dependent variable, and habitat levels, environmental characteristics, and forest structure were explanatory variables. The RDA test was carried out as implemented in BiodiversityR while the glms were fitted through the R package mvabund (Wang et al., 2012). The mvabund functions help test for interactions through multiple testing to predict abundance between sites or treatments. The primary function of mvabund (manyglm) fits a glm to each species in the dataset using a common group of environmental variables. This approach uses a resampling-based hypothesis testing to infer which environmental variables relate to multivariate abundances at community or taxon-specific levels (Wang et al., 2012). The independence of the abundance estimates across sampling sites, as well as the quadratic mean-variance and log linearity in the dataset, were checked through the functions plot and meanvar.plot, as implemented in the same package before fitting the models. Several glms were fitted to tests for variable effects. The data set included the mangrove degradation condition as a categorical variable within the environmental matrix. We performed the same analysis but with the data grouped by functional groups according to the birds primary source of food: insectivores, nectarivores, scavengers, macroinvertivores (polychaetes, mollusks, crustaceans), frugivores, omnivores, and meat eaters (fishes, small reptilians, amphibians, and mammals). Because of the difficultly of measuring this directly in the field, this group classification was sourced from literature on local species (Mackinnon, 2013; Fagan \& Komar, 2016), and from specialized web 
278 sources (https://www.allaboutbirds.org). Models were ranked according to the Akaike's

279 information criterion (AIC) (Burnham \& Anderson, 2002; Burnham, Anderson \& Huyvaert, 280 2011). All tests were set to be significant at 0.05 level, if not indicated otherwise.

281

\section{Results}

283 Pearson's test of conditional independence showed that although the sampling points in each site 284 were closely located, they were independent $\left(\chi^{2}=26.166, \mathrm{df}=20, p=0.1604\right)$. Similarly, no 285 evidence of spatial autocorrelation of the abundance was detected across sampling points 286 (Moran's Index value $=0.0074, p=0.3335$ ).

287

\section{Water quality parameters and forest structure}

289 The frequency of flooding was approximately two and three times greater at the restored and 290 undisturbed sites, respectively, than at the disturbed one (ANOVA test $F_{2,18}=12.47, p=0.003$, 291 Fig. S1). However, there were no significant differences among treatments in tidal range or 292 flooding duration (ANOVA test $F_{2,18}=2.259, p=0.133 ; F_{2,18}=2.416, p=0.118$, respectively).

293 Environmental variables such as salinity concentration, water depth, $\mathrm{pH}$, and temperature were 294 found to be statistically different among sites (Table 1). The mangrove structure also showed 295 significant differences between sites in terms of the number of tree species, basal area, and tree 296 density (Table 1). However, due to the size of the remaining live trees in the disturbed and 297 restored sites, no statistical differences in the heights of trees between sampled sites were 298 observed (Fig. S2). Finally, the ORP values were not statistically different between treatments. 299 However, the ongoing water exchange due to the greater frequency of flooding in the 300 undisturbed and restored areas might indicate higher oxygen concentration in the water (all ORP 301 values were positive).

302

303 Species diversity and abundance

304 Fifty-three avian species were recorded in the surveys across the sampling sites (Table S1). One 305 of them, the Reddish Egret (Egretta rufescens) is near threatened while the rest are of least 306 concern according to the IUCN (2016). Regionally, five species are under special protection, and 307 one, the Yellow-crowned Night-heron (Nyctanassa violacea), is a threatened species 
308 (SEMARNAT, 2010). For almost half of the recorded species (49\%), the populations are

309 trending to increase while $24.5 \%$ show a decreasing trend (IUCN, 2016).

310 The total bird species richness was higher in the disturbed and restored than in the undisturbed

311 site, and, for all sampling sites, the observed species richness was lower than expected (Table 2).

312 This result is consistent with our empirical knowledge of the bird community found in the

313 vicinity of our sampling sites. For instance, species such as the migrant Lesser Scaup (Aythya

314 affinis), the Northern Pintail (Anas acuta), and the American Wigeon (Anas americana), as well

315 as the resident mangrove inhabitants, the Muscovy Duck (Cairina moschata) and the White-

316 fronted Parrot (Amazona albifrons) (both with important population declines in Mexico), were

317 expected but not observed. Diversity indexes showed that there is a clear dominance of few

318 species belonging to the families Ardeidae and Threskiornithidae, especially in the restored site.

319 Even though our sampling effort captured most of the species richness in the study area, the

320 species saturation curve did not reach a flat shape at the end of the surveys (Fig. S3).

321 Accordingly, an increased sampling effort might be necessary to show the true richness of the

322 study area. When pooled data were analyzed, the most abundant species were the Least

323 Sandpiper (Calidris minutilla), the Mangrove Warbler, the Black-bellied Whistling Duck

324 (Dendrocigna autumnalis), the Green Heron (Butorides virescens), the White Ibis (Eudocimus

325 albus), and the Great-tailed Grackle (Quiscalus mexicanus). Because birds detected in flight

326 were only about $10 \%$ of all counts and because there were no statistical differences in the

327 abundance between the whole set of data vs. the data that excluded birds detected in flight

328 (Wilcoxon's test with continuity correction, $\mathrm{W}=1505.5, p=0.7716$ ), for further analyses, we

329 used the full dataset. Species abundance and evenness were similar for undisturbed and disturbed

330 sites. Although the restored site showed higher bird abundance, this was also the location with

331 the least evenness in species distribution. For instance, higher numbers of species such as the

332 Least Sandpiper and the White Ibis, which depend on mangrove habitats with open or semi-open

333 forest structure, were observed in the restored mangrove patches, while the Mangrove Warbler,

334 the Tropical Kingbird (Tyrannus melancholicus), and the American White Pelican (Pelecanus

335 erythrorhynchos) were the least abundant at this site (Fig. 2).

336 The RDA model was statistically significant (Pseudo- $F_{8,24}=2.57, p=0.030$ ), but only a small

337 part of the variation in species abundance within sampling sites was explained by environmental

338 variables since the proportion of unconstrained variance was larger than that of the constrained

Peer] reviewing PDF | (2019:01:34518:3:0:NEW 12 Jul 2019) 
339 (0.53 and 0.46, respectively, after 500 permutations for all eigenvalues). When only the first

340 eigenvalue was analyzed, no significant influence of the environmental variables on birds

341 abundance was observed (Fig. S4); however, a trend in some variables such as water

342 temperature, salinity, and tree density to influence the number of birds across sampling sites was

343 detected (Pseudo- $\left.F_{1,24}=17.97, p=0.055\right)$. To explore the effects of environmental variables on

344 the abundance of birds further, five glms were fitted: one with only environmental variables and

345 not accounting for habitat condition and others that included habitat condition and multiple

346 interactions between environmental variables; however, none of these reached convergence.

347 Thus, the analysis was restricted to additive models between habitat condition and environmental

348 variables. Because $\mathrm{pH}$ and water depth showed high correlation with salinity (Spearman's rank

349 correlation $\mathrm{Rho}=0.486, p=0.001$; Rho $=-0.595, p=0.001$, respectively), these two variables

350 were dropped from the models. According to the AIC scores, the best models showed significant

351 effects of the environmental variables and forest structure on the abundance of bird species

352 (Table S2). Habitat condition, i. e., the condition of the mangrove as disturbed, restored or

353 undisturbed, showed more substantial effects on the number of detected birds as well as on the

354 distribution of the bird guilds across sites (Fig. 3). Additionally, vegetation cover, as well as the

355 number of tree species, also significantly positively influenced the birds' abundance (Table 3A).

356 When the same models were fitted to each single species, neither environmental variables nor the

357 habitat condition showed significant effects on the estimated abundances (Padj $=0.730-0.900$

358 for all species and all variables). The multivariate analysis by functional group showed that only

359 detectability significantly influenced the abundance of bird guilds, while the other variables did

360 not show significant effects on the abundance of any of the analyzed functional groups (Table

361 3B). Similar to the univariate results by species, no significant result was observed when

362 functional groups were analyzed separately $($ Padj $=0.172-0.932$ for all groups and all

363 variables).

364

365 Key species in mangrove forests

366 According to the similar percentage analysis, wader bird species, such as the Least Sandpiper,

367 the White Ibis, and the Great Egret (Ardea alba) are more associated with the disturbed site.

368 Insectivores such as the Yellow Warbler and the Tropical Kingbird, along with the Green Heron, 369 were more associated with the undisturbed habitat condition. The species associated with the 
370 restored site were the Least Sandpiper, the insectivorous Yellow Warbler, and the Green Heron

371 (Table 4). Even though the estimated IndVal value suggested that three bird species might be

372 considered indicators of the different habitat conditions, these results were not significant (Table 373 5).

374

375 Discussion

376 The restored tidal channels allowed more frequent water exchange between the Bahamitas

377 estuary and the Laguna de Términos, which increased the frequency of flooding. This, in turn,

378 improved the mangrove soil quality by decreasing the salinity and enabled the natural

379 regeneration of the forest cover. Such changes positively impacted the abundance of

380 insectivorous birds. When comparing the undisturbed and restored sites with the disturbed areas,

381 in the latter, larger duration of flooding favors anaerobic conditions, hindering the oxidation and

382 enabling the rising of soil sulfides concentration (Reddy \& Delaune, 2008), which affects the

383 ecophysiological functioning of individual plants and is toxic to aquatic fauna (Lamers et al.,

384 2013). On the other hand, the lack of connectivity with the main lagoon and the absence of

385 mangrove vegetation, as well as the low water exchange and higher rate of evaporation are

386 factors causing higher $\mathrm{pH}$ and salinity conditions (Tam et al., 2009, Molnar et al., 2014). These

387 conditions are also likely inhibiting the establishment and growth of seedlings and plants. This

388 effect has been observed in other areas of Laguna de Términos (Agraz-Hernández et al., 2015).

389 By contrast, the undisturbed site showed more frequent water exchange and dense vegetation

390 cover, leading to slower evaporation rate and lower salinity, as posited by Lee et al. (2008).

391 Although there were not yet statistical dissimilarities between the disturbed and the restored

392 sites, only three years after restoration, the opening and desilting of tidal channels brought down

393 the porewater salinity values (Fig. 4) and other components of water quality in the restored site,

394 being overall more similar to the undisturbed site than to the disturbed one, which probably

395 helped to increase the tree canopy cover, litterfall production and tree growth (Kathiresan \&

396 Bingham, 2001; Kathiresan, 2002; Polidoro et al., 2010; Kamali \& Hashim, 2011). This effect in

397 mangroves has been demonstrated in other sites of the coast of Campeche, where higher rates of

398 litterfall production are associated with lower water salinity (Chan-Keb et al., 2018). Besides the

399 fishing and mud-foraging species characteristic of estuarine areas (Kobza et al., 2004), higher 
400 litterfall productivity, in turn, broadens the spectrum of resources by increasing niches for 401 insectivorous birds' prey species in the restored sites.

402 Both the disturbed and restored sites showed higher bird abundance and species richness than the 403 undisturbed one. This is similar to the findings reported in structurally complex habitats and 404 island setting, which are found to be more diverse if their habitats show heterogeneity (Acevedo 405 \& Aide, 2008; Jones, Marsden \& Linsley, 2003), even if they are disturbed, as were two of our 406 study sites. The results from the models highlight the fact that more heterogeneous habitats such 407 as the restored site and, to some extent, the disturbed one result in more species-rich places, 408 allowing for the existence of more structured bird communities than in the more homogenous 409 undisturbed site (Báldi, 2008). This effect is present because high-quality undisturbed mangrove patches surround the disturbed and restored mangrove sites, increasing their heterogeneity.

412 from the restored and disturbed sites to feed or rest, bird species that prefer open and semi-open 413 habitats (sandpipers, avocets, cormorants, etc.) are not present in the densely vegetated 414 undisturbed mangrove. They take advantage of the open areas at the disturbed site, which are 415 adequate foraging niches for waders because of the long-lasting floods there. Accordingly, the 416 high abundance of these species could be indicative of sites with impacts affecting the 417 hydroperiod or the vegetation cover. Because of mangrove forests being structurally 418 homogenous when compared to other forest habitats (Mohd-Azlan, Noske \& Lawes, 2015), the 419 number of bird species recorded was not as high as expected when surveys include another type 420 of tropical forests. This outcome might also be due to habitat preferences of the different bird 421 species recorded, or could be the effect of short-term monitoring (Canterbury et al., 2000).

422 However, the effects of the sampling duration and size might be negligible, since the 423 heterogeneity of the forest structure traits, such as cover and composition, results in a more 424 complex assemblage of bird communities at the landscape level (Kroll et al., 2014). Hence, the avian community structure might be more influenced by the heterogeneity, diversity and phenology of the mangrove forest than by the size of the sampled sites (Mohd-Azlan, Noske \& Lawes, 2012). Moreover, Chacin et al. (2015) demonstrated that hydrological fragmentation does not always negatively affect avian abundance since the loss of hydrological connectivity might result in prey concentration, facilitating forage activities for some species of fishing birds. We agree with this hypothesis but only if tidal patterns allow a cyclic interruption-reconnection of 
431 the main and secondary tidal channels to allow flooding and drainage of the mangrove sites. The 432 results of the multivariate analysis supported this idea. Moreover, it demonstrated that bird 433 abundance was more influenced by habitat condition (i. e. hydroperiod and forest structure) than 434 by the measured water parameters. Although there were no clear biological effects of the 435 measured water parameters on the abundance of the birds in our study area, they surely 436 determine resource availability because of their effect on the primary producers, and hence on 437 the presence of the benthonic, fish and crustacean communities (Holguin, Vazquez \& Bashan, 438 2001; Sandilyan \& Kathiresan, 2015), on which many bird species feed.

439 As the characteristics of the habitat influence the distribution of wading species, the sites with 440 less canopy cover provide better foraging areas for waders (Bancroft, Gawlik \& Rutchey, 2002; 441 Curado et al., 2013). Additionally, the selection of open and semi-open areas likely reduces the 442 predation risk and increases the foraging efficiency of wading species (Pomeroy, 2006; Chacin et 443 al., 2015). Notwithstanding, while tall and broad canopy vegetation might negatively affect the 444 foraging efficiency of water birds, it might become more beneficial for the insectivores (Tavares $445 \&$ Siciliano, 2013). Thus, the presence of wading and diving, together with canopy and 446 undergrowth species using the edges of primary habitat and the emerging vegetation within the 447 restored site, may have influenced the proportions of bird abundance and richness in the study 448 area.

449 Because our sampling sites are located within a landscape matrix of disturbed and undisturbed 450 patches, the geographical distribution of the study locations likely influenced the number of 451 species found in each sampling site. For example, recordings of birds common to undisturbed 452 sites, such as the Mangrove Warbler, were relatively frequent in the restored and disturbed sites 453 because this species uses features of the disturbed areas as rest spots or merely in the movement 454 between undisturbed patches, as other species do (Mohd-Azlan, Noske \& Lawes, 2015). This 455 behavior might prevent the identification of particular species from each sampling location just 456 on the basis of observation. Thus, estimates of abundance might be a better indicator. For 457 instance, the abundance of the Mangrove Warbler was higher in both undisturbed and restored 458 areas, although we recorded this species in all studied sites. Additionally, based on the species459 by-species abundance, we obtained evidence of non-random use of the restored site as foraging 460 habitats for this and other insectivores (Table 4). 
461 The regrowth of vegetation cover induced by the restoration activities, demonstrated by the 462 increase in the height $(0-55 \mathrm{~cm})$ of the mangrove scrub and increased recruitment $(0-79$ 463 individualsha ${ }^{-1}$ ) (see Echeverría-Ávila et al., 2019), improved the availability of resources and, 464 hence, the presence and the abundance of insectivorous birds such as the Mangrove Warbler and 465 the Tropical Kingbird. A very close relative of the former, the Yellow Warbler (Setophaga 466 petechia), has been considered a key species because of its sensitivity to changes in 467 environmental conditions and specific habitat needs (Lowther et al., 1999), and because its 468 populations may change according to the habitat management practices and food availability 469 (Salgado-Ortiz, Marra \& Robertson, 2009). Since the higher abundance of the Mangrove 470 Warbler was apparently related to the undisturbed areas, it demonstrates its importance as an 471 indicator of habitat with negligible impacts, or of habitats showing signs of recovery. Also, the 472 open and semi-open areas in the restored site contributed to the higher availability of resources 473 for different bird guilds (Ortega-Alvarez \& Lindig-Cisneros, 2012; Buelow \& Sheaves, 2015). 474 These areas were more attractive to birds which usually flock in large groups and forage on the 475 ground, mud or inundated areas, leading to higher abundances than in the densely-vegetated 476 undisturbed site. Even though the IndVal was non-significant, both approaches used to identify 477 key species suggested that insectivores better represented the undisturbed site. According to the 478 Simper analysis, the species that best represents the restored mangrove is a meat-eater (the Green 479 Heron), whereas the IndVal suggested that an omnivore (the Blue-winged Teal [Anas discors]) 480 could be an indicator for this site. This lack of coincidence might relate to differing information 481 used by each approach. While Simper uses only the information regarding abundance, IndVal 482 uses the relative abundance and also incorporates the relative frequency of occurrence.

483 Additionally, the presence of species such as ibises and wood storks is considered evidence of 484 success after the implementation of restoration activities (Ortega-Alvarez \& Lindig-Cisneros, 485 2012; Zhao et al., 2016). This is because they depend mostly on communities of vertebrates and 486 invertebrates that are sensitive to changes in water and soil quality, induced among other factors, 487 by the alteration of the hydroperiod (Ogden et al., 2014). Accordingly, the presence and 488 abundance of the insectivorous and wading bird species similar to those found in the study area 489 are important elements by which to evaluate and monitor the effectiveness of habitat restoration 490 projects in mangrove ecosystems. 


\section{Implications for Conservation}

493 There is no doubt that natural phenomena, such as hurricanes, contribute to habitat heterogeneity. 494 However, severe climatic events may alter the microtopography and hydrological connectivity 495 and make difficult post-hurricane natural regeneration. Such is especially the case in habitats that 496 depend on recurrent flooding and drainage (hydroperiods) such as mangroves. By altering the 497 hydroperiod, dead mangrove areas may increase in size through time. The loss of the vegetation 498 cover and the alteration of the environmental conditions may, in turn, lead to biotic 499 homogenization (Martínez-Ruíz \& Renton, 2017). After degradation due to loss of hydrological 500 connectivity occurs in mangroves, restoration of water flow through deblocking of main and 501 secondary tidal channels increases the habitat heterogeneity, allowing the resettlement of 502 ecosystem services and strengthening the ecological relationships and structure of the biotic 503 communities living there. It may also improve the hydro-edaphic factors, such as nutrients, water 504 level, and porewater salinity (McKee et al., 2002), from which the micro and macrobenthos, as 505 well as fisheries and birds, are dependent.

506 Long flooding periods limit the abundance of wading birds, especially the small species foraging 507 on the macrobenthos. Thus, identifying degraded areas and monitoring the hydroperiod, before 508 and after of hydrological restoration, will allow for better conservation strategies for the 509 mangroves and their avian communities. As the hydrological connectivity improves mangrove 510 heterogeneity by regenerating vegetation, avian communities can become more diverse, 511 acquiring a higher number of species from different functional groups. Thus, densely vegetated 512 mangroves, together with the restoration of patches unable to regenerate themselves, are essential 513 to maximizing the abundance of specialized bird guilds.

514 To realize the positive effects of restoration activities, it is necessary to create a link between the 515 restoration programs and the local communities through environmental and economic 516 development education. For instance, birdwatching and sport fishing (catch and release) can be 517 alternatives to socio-economic growth for the benefit of human coastal communities through the 518 development of a green touristic industry in restored places (Skelton \& Allaway, 1996).

519 We expect that the restoration activities implemented will increase and maintain the habitat's 520 heterogeneity in the medium and the long term and will strengthen the resilience of the 521 mangrove forests.

522 


\section{Conclusions}

524 The restoration activities in the estuaries of Laguna de Términos first helped the natural

525 regeneration of the mangrove forest through the water movement caused by the opening and

526 desilting of tidal channels, making tidal periodicity comparable to that of natural conditions

527 while also reducing water salinity. In addition, water exchange likely favored fish and crustacean

528 production and the appearance of mudflat and shallow water zones, which are attractive foraging

529 areas for different bird guilds. Consequently, habitat heterogeneity and the availability of

530 resources increased, and the avian community became more diverse, especially regarding the

531 abundance of insectivorous birds in the restored areas.

532

\section{Acknowledgements}

534 We thank Herminia Rejón Salazar and the 'Community of Mangrove Restorers' from Isla

535 Aguada for their support with the field work, Emma Guevara Carrió, Mario Alejandro Gómez

536 Ponce, Hernán Álvarez Guillén and Andrés Reda Deara for their assistance with logistics and

537 field data collection. To José Nava from CONANP-Laguna de Términos for the facilities to carry

538 out our surveys.

539

540

541 References

542 Acevedo M, Aide T. 2008. Bird community dynamics and habitat associations in karsts,

543 mangrove and Pterocarpous forest fragments in an urban zone in Puerto Rico. Caribbean Journal

544 of Science 44: 402-416

545 Adame M, Fry B, Gamboa J, Herrera-Silveira J. 2015. Nutrient subsidies delivered by seabirds

546 to mangrove islands. Marine Ecology Progress Series 525:15-4

547 Agraz-Hernández CM, Chan-Keb CA, Iriarte-Vivar S, Posada Venegas, G, Vega Serratos B, Osti

548 Sáenz J. 2015. Phenological variation of Rhizophora mangle and ground water chemistry

549 associated to changes of the precipitation. Hidrobiológica 25:49-61

550 Alongi DM. 2008. Mangrove forests: Resilience, protection from tsunamis, and responses to

551 global climate change. Estuarine, Coastal and Shelf Science 76:1-13

552 Amir AA. 2018. Mitigate risk for Malaysia’s mangroves. Science 359: 1342.2-1343. 
553 Anderson MJ, Gorley RN, Clarke KR. 2008. PERMANOVA+for PRIMER: Guide to Software and 554 Statistical Methods. Plymouth, UK.

555 Andrade LL, Leite D, Ferreira E, Ferreira L, Paula GR, Maguire M, Hubert C, Peixoto R,

556 Domingues R, Rosado A. 2012. Microbial diversity and anaerobic hydrocarbon degradation

557 potential in an oil-contaminated mangrove sediment. BMC Microbiology 12:186

558 Azhar B, Lindenmayer DB, Wood J, Fischer J, Manning A, McElhinny C, Zakaria M. 2013. The

559 influence of agricultural system, stand structural complexity and landscape context on foraging

560 birds in oil palm landscapes. Ibis 155:297-312

561 Báldi A. 2008. Habitat heterogeneity overrides the species-area relationship. Journal of

562 Biogeography 35:675-681

563 Bancroft GT, Gawlik DE, Rutchey K. 2002. Distribution of Wading Birds Relative to Vegetation 564 and Water Depths in the Northern Everglades of Florida, USA. Waterbirds 25:265-391

565 Battisti C, Dodaro G, Franco D. 2014. The data reliability in ecological research: a proposal 566 for a quick self-assessment tool. Natural History Sciences 1:75-79

567 Behrouzi-Rad B. 2014. Population Dynamic and Species Diversity of Wintering Waterbirds in 568 Mangroves Wetland (Persian Gulf) in 1983 and 2013. International Journal of Marine Science $569 \quad 4: 1-7$

570 Bibby CJ, Burgess ND, Hill DA, Bibby CJ, Burgess ND, Hill DA. 1992. Bird Census

571 Techniques. London, Academic Press.

572 Boyle RA, Dorn NJ, Cook MI. 2012. Nestling Diet of Three Sympatrically Nesting Wading Bird 573 Species in the Florida Everglades. Waterbirds 35:154-159

574 Bryce SA, Hughes RM, Kaufmann PR. 2002. Development of a bird integrity index: Using bird 575 assemblages as indicators of riparian condition. Environmental Management 30:294-310

576 Buelow C, Sheaves M. 2015. A birds-eye view of biological connectivity in mangrove systems.

577 Estuarine, Coastal and Shelf Science 152:33-43

578 Burnham K, Anderson D. 2002. Model Selection and Multimodel Inference: A Practical

579 Information-Theoretic Approach. Springer Verlag, New York.

580 Burnham KP, Anderson DR, Huyvaert KP. 2011. AIC model selection and multimodel inference 581 in behavioral ecology: Some background, observations, and comparisons. Behavioral Ecology 582 and Sociobiology 65:23-35 
583 Canterbury GE, Martin TE, Petit DR, Petit LJ, Bradford DF. 2000. Bird communities and habitat

584 as ecological indicators of forest condition in regional monitoring. Conservation Biology 14:544 $585 \quad 558$

586 Catterall CP, Freeman AND, Kanowski J, Freebody K. 2012. Can active restoration of tropical

587 rainforest rescue biodiversity? A case with bird community indicators. Biological Conservation 588 146:53-61

589 Chacin DH, Giery ST, Yeager LA, Layman CA, Brian-Langerhans R. 2015. Does hydrological 590 fragmentation affect coastal bird communities? A study from Abaco Island, The Bahamas.

591 Wetlands Ecology and Management 23:551-557

592 Chan-Keb CA, Agraz-Hernández CM, Muñiz-Salazar R, Posada-Vanegas G, Osti-Sáenz J,

593 Reyes Castellano JE, Conde-Medina KP, Vega-Serratos BE. 2018. Ecophysiological Response

594 of Rhizophora mangle to the Variation in Hydrochemistry during Five Years along the Coast of

595 Campeche, México. Diversity 10:9

596 Chape S, Spalding M, Jenkins M. 2008. The World's Protected Areas: Status, Values and

597 Prospects in the 21st Century. University of California, Berkeley, USA.

598 Clarke KR. 1993. Non-parametric multivariate analyses of changes in community structure.

599 Australian Journal of Ecology 18:117-143

600 Costanza R, de Groot R, Sutton P, van der Ploeg S., Anderson SJ, Kubiszewski I, Farber S,

601 Turner, R. K. 2014. Changes in the global value of ecosystem services. Global Environmental

602 Change 26:152-158

603 Crase B, Liedloff A, Vesk PA, Burgman MA, Wintle BA. 2013. Hydroperiod is the main driver

604 of the spatial pattern of dominance in mangrove communities. Global Ecology and

605 Biogeography 22: 806-817.

606 Curado G, Figueroa E, Sanchez MI, Castillo JM. 2013. Avian communities in Spartina maritima

607 restored and non-restored salt marshes. Bird Study 60:185-194

608 Cui B, Yang Q, Yang Z, Zhang K. 2009. Evaluating the ecological performance of wetland

609 restoration in the Yellow River Delta, China. Ecological Engineering 35:1090-1103

610 Cvetkovic M, Chow-Fraser P. 2011. Use of ecological indicators to assess the quality of Great

611 Lakes coastal wetlands. Ecological Indicators 11:1609-1622

612 David LT, Kjerfve B. 1998. Tides and currents in a two-inlet coastal lagoon: Laguna de

613 Términos, México. Continental Shelf Research 18:1057-1079 
614 Donato DC, Kauffman JB, Murdiyarso D, Kurnianto S, Stidham M, Kanninen M. 2011.

615 Mangroves among the most carbon-rich forests in the tropics. Nature Geoscience 4:293-297

616 Echeverría-Ávila S, Pérez-Ceballos R, Zaldívar-Jiménez A, Canales-Delgadillo J, Brito-Pérez R,

617 Merino-Ibarra M, Vovides A. 2019. Regeneración natural de sitios de manglar degradado en

618 respuesta a la restauración hidrológica. Madera y Bosques 25: e2511754. doi:

$619 \quad 10.21829 / \mathrm{myb} .2019 .2511754$

620 Fagan J, Komar O. 2016. Field Guide to Birds of Northern Central America. HMH Publishing

621 Company, New York, NY.

622 Frederick P, Gawlik DE, Ogden JC, Cook MI, Lusk M. 2009. The White Ibis and Wood Stork as

623 indicators for restoration of the Everglades ecosystem. Ecological Indicators 9: S83-S95

624 Gardner CJ, de Ridder C, de Ridder B, Jasper LD. 2012. Birds of Ambondrolava mangrove

625 complex, Southwest Madagascar. Check List 8:1-7

626 Giri C, Ochieng E, Tieszen LL, Zhu Z, Singh A, Loveland T, Masek J, Duke N. 2011. Status

627 and distribution of mangrove forests of the world using earth observation satellite data. Global

628 Ecology and Biogeography 20:154-159.

629 Gotelli NJ, Colwell RK. 2011. Estimating species richness. In: Levin S.A., ed. Biological

630 Diversity: Frontiers in Measuring Biodiversity. New York, Oxford University Press, 39-54.

631 Gregory RD, Gibbons DW, Donald PF. 2004. Bird census and survey techniques. In: Sutherland,

632 WJ, Newton I, Green R, eds. Bird Ecology and Conservation. Oxford, Oxford University Press, $63317-56$.

634 Gyurácz J, Bánhidi P, Csuka A. 2011. Successful restoration of water level and surface area 635 restored migrant bird populations in a Hungarian wetland. Biologia 66: 1177. doi:

$63610.2478 / \mathrm{s} 11756-011-0132-0$

637 Hauser LT, Nguyen Vu G, Nguyen BA, Dade E, Nguyen HM, Nguyen TTQ, Le TQ, Vu LH,

638 Tong ATH, Pham HV. 2017. Uncovering the spatio-temporal dynamics of land cover change and

639 fragmentation of mangroves in the Ca Mau peninsula, Vietnam using multi-temporal SPOT

640 satellite imagery (2004-2013). Applied Geography 86: 197-207.

641 Holguin G, Vazquez P, Bashan Y.2001. The role of sedimentmicroorganisms in the productivity, 642 conservation, and rehabilitation of mangrove ecosystems: an overview. Biology and Fertility of 643 Soils 33:265-278. 
644 Ingram J. 2008. Berger-Parker Index. In: Jorgensen SE, Fath BD, eds. Encyclopedia of Ecology. 645 Oxford, Elsevier, 332-334.

646 IUCN. 2016. The IUCN Red List of Threatened Species. Version 2016-3.

647 Jones MJ, Marsden SJ, Linsley MD. 2003. Effects of habitat change and geographical variation

648 on the bird communities of two Indonesian islands. Biodiversity and Conservation 12:1013-1032

649 Kamali B, Hashim R. 2011. Mangrove restoration without planting. Ecological Engineering $650 \quad 37: 387-391$.

651 Kathiresan K. 2002. Why are mangrove degrading? Current Sicience, 83(10):1246-1249.

652 Kathiresan K, Bingham B. 2001. Biology of mangroves and mangrove Ecosystems. Advances in

653 Marine Biology 40:81-251

654 Kindt R, Coe R. 2005. Tree diversity analysis: A manual and software for common statistical 655 methods for ecological and biodiversity studies. Nairobi, Kenya, World Agroforestry Center. 656 Kobza M, Trexler JC, Loftus WF, Perry SA. 2004. Community structure of fishes inhabiting 657 aquatic refuges in a threatened Karst wetland and its implications for ecosystem management. 658 Biological Conservation 116:153-165

659 Krauss KW, Doyle TW, Twilley RR, Rivera-Monroy VH, Sullivan JK. 2006. Evaluating the 660 relative contributions of hydroperiod and soil fertility on growth of south Florida mangroves. 661 Hydrobiologia 569: 311-324

662 Kroll AJ, Ren Y, Jones JE, Giovanini J, Perry RW, Thill RE, White D, Wigley TB. 2014. Avian 663 community composition associated with interactions between local and landscape habitat 664 attributes. Forest Ecology and Management 326:46-57

665 Lamers L, Govers L, Janssen I, Geurts J, Van der Welle M, Van Katwijk M, Van der Heide T, 666 Roelofs J, Smolders A. 2013. Sulfide as a soil phytotoxin — a review. Frontiers in Plant Science $667 \quad 4: 268$

668 Lantz SM, Gawlik DE, Cook MI. 2011. The Effects of Water Depth and Emergent Vegetation on 669 Foraging Success and Habitat Selection of Wading Birds in the Everglades. Waterbirds 34:439$670 \quad 447$

671 Lavoie RA, Champoux L, Rail JF, Lean DRS. 2010. Organochlorines, brominated flame 672 retardants and mercury levels in six seabird species from the Gulf of St. Lawrence (Canada): 673 Relationships with feeding ecology, migration and molt. Environmental Pollution 158:21896742199. 
675 Lee RY, Porubsky WP, Feller IC, McKee KL, Joye SB. 2008. Porewater biogeochemistry and soil 676 metabolism in dwarf red mangrove habitats (Twin Cays, Belize). Biogeochemistry 87:181-198 677 Lee SY, Primavera JH, Dahdouh-Guebas F, McKee K, Bosire JO, Cannicci S, Diele K, Fromard 678 F, Koedam N, Marchand C, Mendelssohn I, Mukherjee N, Record S. 2014. Ecological role and 679 services of tropical mangrove ecosystems: a reassessment. Global Ecology and Biogeography 680 23: 726-743. doi: 10.1111/geb.12155.

681 Li D, Chen S, Guan L, Lloyd H, Liu Y, Lv J, Zhang Z. 2011. Patterns of waterbird community 682 composition across a natural and restored wetland landscape mosaic, Yellow River Delta, China. 683 Estuarine, Coastal and Shelf Science 91: 325-332.

684 Lowther PE, Celada N, Klein C, Rimner C, Spector DA. 1999. Yellow Warbler (Dendroica 685 petechia). In: Poole A, Gill F, eds. The Birds of North America, No. 454. Ithaca, New York, The 686 Birds of North America Online.

687 MacKinnon B. 2013. Sal a Pajarear Yucatán (Guía de Aves). La Vaca Independiente S. A. de C. 688 V., México.

689 Martínez-Ruiz M, Renton K. 2018. Habitat heterogeneity facilitates resilience of diurnal raptor 690 communities to hurricane disturbance. Forest Ecology and Management 426: 134-144.

691 McElhinny C, Gibbons P, Brack C, Bauhus J. 2005. Forest and woodland stand structural 692 complexity: Its definition and measurement. Forest Ecology and Management 218: 1-24. 693 McFadden TN, Kauffman JB, Bhomia RK. 2016. Effects of nesting waterbirds on nutrient levels 694 in mangroves, Gulf of Fonseca, Honduras. Wetlands Ecology and Management 24:217-229.

695 McKee KL, Feller IC, Popp M, Wanek W.2002. Mangrove isotopic ( $\delta 15 \mathrm{~N}$ and $\delta 13 \mathrm{C})$

696 fractionation across a nitrogen vs. phosphorus limitation gradient. Ecology 83:1065-1075.

697 Mohd-Azlan J, Noske RA, Lawes MJ. 2012. Avian species-assemblage structure and indicator 698 bird species of mangroves in the Australian monsoontropics. Emu - Austral Ornithology112:287699297.

700 Mohd-Azlan J, Noske R, Lawes M. 2015. The Role of Habitat Heterogeneity in Structuring 701 Mangrove Bird Assemblages. Diversity 7(2):118-136.

702 Molnar N, Marchand C, Deborde J, Della Patrona L, Meziane T. 2014. Seasonal Pattern of the 703 Biogeochemical Properties of Mangrove Sediments Receiving Shrimp Farm Effluents (New 704 Caledonia). Journal of Aquaculture Research \& Development 05:1-13. 
705 Nagelkerken I, Blaber SJM, Bouillon S, Green P, Haywood M, Kirton LG, Meynecke JO,

706 Pawlik J, Penrose HM, Sasekumar A, et al. 2008. The habitat function of mangroves for

707 terrestrial and marine fauna: A review. Aquatic Botany 89: 155-185.

708 Nilsson C, Aradottir AL. 2013. Ecological and Social Aspects of Ecological Restoration: New

709 Challenges and Opportunities for Northern Regions. Ecologyand Society 18:35.

710 Ogden JC, Baldwin JD, Bass OL, Browder JA, Cook MI, Frederick PC, Frezza PE, Galvez RA,

711 Hodgson AB, Meyer KD, Oberhofer LD, Paul AF, Fletcher PJ, Davis SM, Lorenz JJ. 2014.

712 Waterbirds as indicators of ecosystem health in the coastal marine habitats of Southern Florida: 2.

713 Conceptual ecological models. Ecological Indicators 44:128-147.

714 Ortega-Alvarez R, Lindig-Cisneros R. 2012. Feathering the Scene: The Effects of Ecological

715 Restoration on Birds and the Role Birds Play in Evaluating Restoration Outcomes. Ecological

716 Restoration 30:116-127.

717 Palmer MA, Hondula KL, Koch BJ. 2014. Ecological Restoration of Streams and Rivers:

718 Shifting Strategies and Shifting Goals. Annual Review of Ecology, Evolution, and Systematics

719 45:247-69.

720 Paradis E, Claude J, Strimmer K. 2004. APE: analyses of phylogenetics and evolution in R

721 language. Bioinformatics, 20: 289-290.

722 Pendleton GW. 1995. Effects of Sampling Strategy, Detection Probability, and Independence of

723 Counts on the Use of Point Counts. Technical report, USDA Forest Service, California.

724 Pérez-Ceballos R, Zaldívar-Jiménez A, Ladrón de Guevara P, Amador del Angel L, Endañú-

725 Huerta E, Guevara-Carrió E, Herrera-Silveira J. 2013. Los manglares de la región Atasta-

726 Sabancuy, Campeche, México. Programa piloto de conservación y restauración de manglares

727 dentro del Proyecto Integral para el Gran Ecosistema Marino del Golfo de México. Technical

728 report, Ciudad del Carmen, Campeche, México.

729 Pohlert T. 2014. The pairwise multiple comparison of mean ranks package (PMCMR). R

730 package. https://CRAN.R-project.org/package=PMCMR.

731 Polidoro BA, Carpenter KE, Collins L, Duke NC, Ellison AM, Ellison JC, Farnsworth EJ,

732 Fernando ES, Kathiresan K, Koedam NE, Livingstone SR, Miyagi T, Moore GE, Nam VN, Ong

733 JE, Primavera JH, Salmo SG, Sanciangco JC, Sukardjo S, Wang Y, Yong JWH. 2010. The loss of

734 species: Mangrove extinction risk and geographic areas of global concern. PLoS ONE 5: e10095. 
735 Pomeroy AC. 2006. Tradeoffs between food abundance and predation danger in spatial usage of

736 a stopover site by western sandpipers, Calidris mauri. Oikos 112:629-637.

737 R Development Core Team. 2013. R: A language and environment for statistical computing. R

738 Foundation for Statistical Computing, Vienna, Austria. URL http://www.R- project.org/.

739 Reddy KR, Delaune RD. 2008. Oxygen. In: Reddy KR, Delaune RD, ed. Biogeochemistry of

740 Wetlands. Boca Raton, Florida, CRC Press, 185-213.

741 Roberts DW. 2016. labdvs: Ordination and multivariate analysis for ecology. R package version

742 1.8-0. http://CRAN.R-project.org/package=labdvs.

743 Royston P. 1995. Remark AS R94: A remark on Algorithm AS 181: The W test for normality.

744 Applied Statistics. 44: 547-551. doi: 10.2307/2986146.

745 Salem ME, Mercer DE. 2012. The Economic Value of Mangroves: A Meta-Analysis.

746 Sustainability 4:359-383.

747 Salgado-Ortiz J, Marra PP, Robertson RJ. 2009. Breeding seasonality of the mangrove warbler

748 (Dendroica petechia bryanti) from southern Mexico. Ornitologia Neotropical 20:255-263

749 Salmo S, Tibbetts I, Duke N. 2016. Colonization and shift of mollusc assemblages as a

750 restoration indicator in planted mangroves in the Philippines. Biodiversity and Conservation

$75126: 865-881$.

752 Sandilyan S, Kathiresan K. 2015. Density of waterbirds in relation to habitats of Pichavaram

753 mangroves, Southern India. Journal of Coastal Conservation 19:131-139.

754 Serafy JE, Shideler GS, Araújo RJ, Nagelkerken I. 2015. Mangroves Enhance Reef Fish

755 Abundance at the Caribbean Regional Scale. PLoS ONE 10: e0142022.

756 Schaffelke B, Mellors J, Duke NC. 2005. Water quality in the Great Barrier Reef region:

757 responses of mangrove, seagrass and macroalgal communities. Marine Pollution Bulletin 51:

$758 \quad 279-296$.

759 Schaeffer-Novelli Y, Vale CC, Cintrón G. 2015. Guia para estudo de áreas de manguezal.

760 Estrutura, função e flora. In: Turra A, Denadai MR, eds. Protocolos para o monitoramento de

761 habitats bentonicos costeiros. Sao Paulo, Instituto Oceanográfico da Universidade de Sao Paulo, $76262-80$.

763 Schmidt JH, McIntyre CL, MacCluskie MC. 2013. Accounting for incomplete detection: What

764 are we estimating and how might it affect long-term passerine monitoring programs? Biological

765 Conservation 160:130-139.

Peer] reviewing PDF | (2019:01:34518:3:0:NEW 12 Jul 2019) 
766

767

768

769

770

771

772

SEMARNAT. 2010. Norma Oficial Mexicana NOM-059-SEMARNAT-2010. Available at http://www.profepa.gob.mx/innovaportal/file/435/1/NOM_059_SEMARNAT_2010.pdf(accessed 26 January 2019).

Skelton NJ, Allaway WG. 1996. Oxygen and pressure changes measured in situ during flooding in roots of the Grey Mangrove Avicennia marina (Forssk.) Vierh. Aquatic Botany 54:165-175

773 Suding K, Higgs E, Palmer M, Callicott JB, Anderson CB, Baker M, Gutrich JJ, Hondula KL,

774 LaFevor MC, Larson BMH, Randall A, Ruhl JB, Schwartz KZS. 2015. Committing to ecological 775 restoration. Science 348:638-640.

776 Tam NFY, Wong AHY, Wong MH, Wong YS. 2009. Mass balance of nitrogen in constructed 777 mangrove wetlands receiving ammonium-rich wastewater: Effects of tidal regime and carbon

778 supply. Ecological Engineering 35:453-462.

779 Tavares DC, Siciliano S. 2013. Variação temporal na abundância de espécies de aves aquáticas 780 em uma lagoa costeira do Norte Fluminense do estado do Rio de Janeiro, sudeste do Brasil.

781 Biotemas 27:121-132.

782 Thornton SR, Johnstone RW. 2015. Mangrove rehabilitation in high erosion areas: Assessment 783 using bioindicators. Estuarine, Coastal and ShelfScience 165: 176-184

784 Turner RE, Lewis RR. 1996. Hydrologic restoration of coastal wetlands. Wetland Ecology and 785 Management 4:65-72.

786 Valderrama L, Troche C, Rodriguez MT, Marquez D, Vázquez B, Velázquez, S, Vázquez A, 787 Cruz MI, Ressl R. 2014. Evaluation of Mangrove Cover Changes in Mexico During the 19707882005 Period. Wetlands 34:747-758.

789 Valiela I, Bowen JL, York JK. 2001. Mangrove Forests: One of the World's Threatened Major 790 Tropical Environments. BioScience 51:807-815.

791 Villalobos-Zapata GJ, Mendoza-Vega J. 2010. La Biodiversidad en Campeche:Estudio de 792 Estado. CONABIO, UAC, ECOSUR, Campeche.

793 Wang M, Zhang J, Tu Z, Gao X, Wang W. 2010. Maintenance of estuarine water quality by 794 mangroves occurs during flood periods: A case study of a subtropical mangrove wetland. Marine 795 Pollution Bulletin 60:2154-2160. 
796 Wang Y, Naumann U, Wright ST, Warton DI. 2012. Mvabund- an R package for model-based 797 analysis of multivariate abundance data. Methods in Ecology and Evolution 3:471-474.

798 Warren-Rhodes K, Schwarz AM, Boyle LN, Albert J, Agalo SS, Warren R, Bana A, Paul C, 799 Kodosiku R, Bosma W, Yee D, Rönnbäck P, Crona B, Duke NC. 2011. Mangrove ecosystem 800 services and the potential for carbon revenue programmes in Solomon Islands. Environmental 801 Conservation 38:485-496.

802 Weller MW. 1995. Use of Two Waterbird Guilds as Evaluation Tools for the Kissimmee River 803 Restoration. Restoration Ecology 3:211-224. doi: 10.1111/j.1526-100X.1995.tb00171.x. 804 Wenny DG, DeVault TL, Johnson MD, Kelly D, H Sekercioglu C, Tomback DF, Whelan CJ. 805 2011. The Need to Quantify Ecosystem Services Provided by Birds. The Auk 128:1-14.

806 Woodroffe CD, Rogers K, McKee KL, Lovelock CE, Mendelssohn IA, Saintilan N. 2016.

807 Mangrove Sedimentation and Response to Relative Sea-Level Rise. Annual Review of Marine 808 Science 8: 243-266.

809 Wortley L, Hero JM, Howes M. 2013. Evaluating ecological restoration success: A review of the 810 literature. Restoration Ecology 21:537-543.

811 Zaldívar-Jiménez A, Herrera-Silveira J, Teutli-Hernandez C, Comin F, Andrade JL, Molina CC, 812 Ceballos RP. 2010. Conceptual Framework for Mangrove Restoration in the Yucatan Peninsula.

813 Ecological Restoration 28:333-342.

814 Zaldívar-Jiménez A, Ladrón de Guevara-Porras P, Pérez-Ceballos R, Díaz-Mondragón S,

815 Rosado-Solórzano R. 2017. US-Mexico joint gulf of Mexico large marine ecosystem based 816 assessment and management: Experience in community involvement and mangrove wetland 817 restoration in Términos Lagoon, Mexico. Environmental Development 22:206-213.

818 Zhang JP, Shen CD, Ren H, Wang J, Han WD. 2012. Estimating Change in Sedimentary Organic 819 Carbon Content During Mangrove Restoration in Southern China Using Carbon Isotopic 820 Measurements. Pedosphere 22:58-66.

821 Zhao Q, Bai J, Huang L, Gu B, Lu Q, Gao Z. 2016. A review of methodologies and success

822 indicators for coastal wetland restoration. Ecological Indicators 60:442-452.

823 Zou Y, Liu J, Yang X, Zhang M, Tang C, Wang T. 2014. Impact of coastal wetland restoration 824 strategies in the chongming dongtan wetlands, China: Waterbird community composition as an 825 indicator. Acta Zoologica Academiae Scientiarum Hungaricae 60: 185-198. 
Figure 1

Location of Bahamitas estuaries with different disturbance levels in Laguna de Términos, Campeche Mexico.

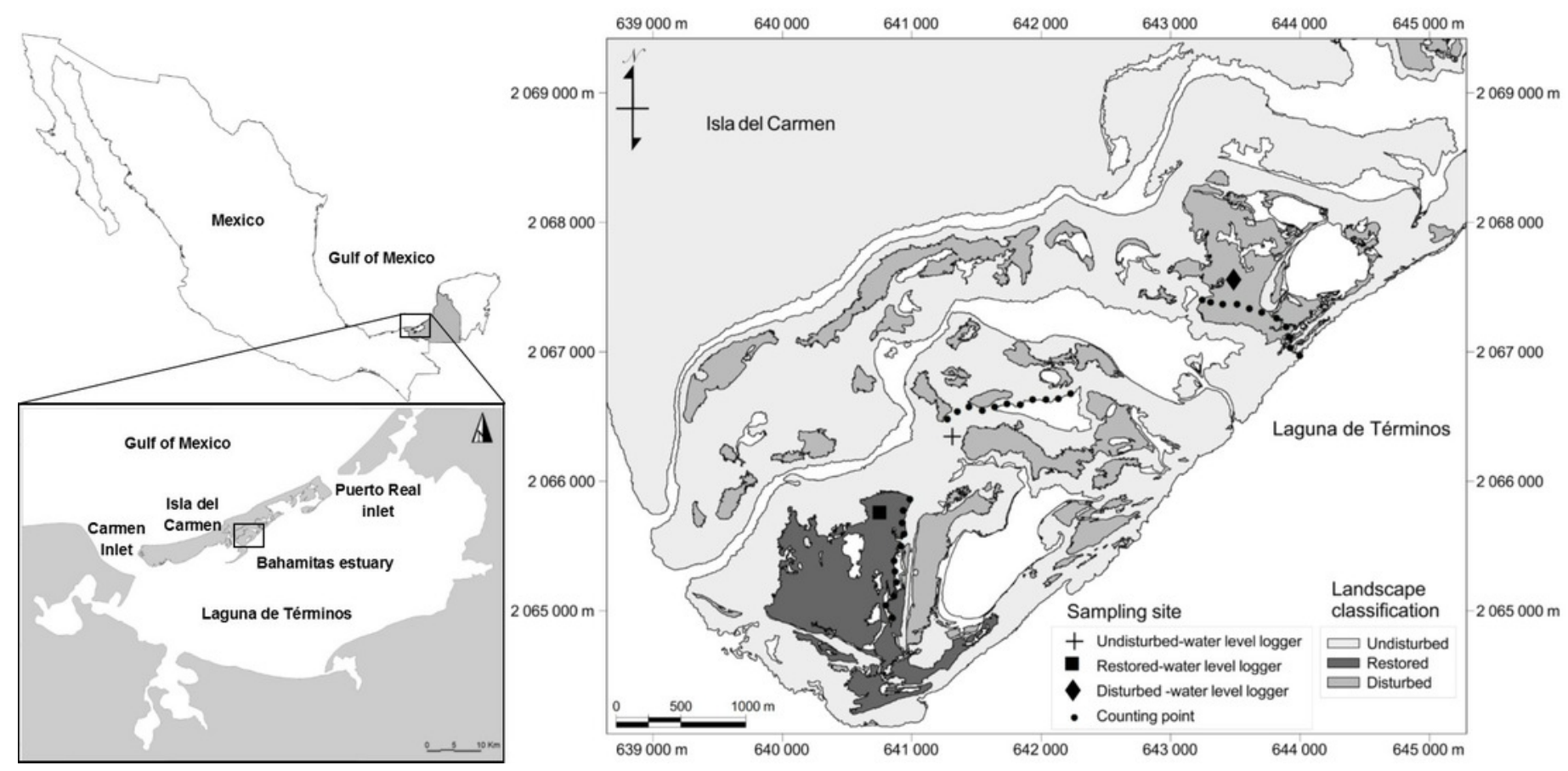


Figure 2

Ranking of the abundance of bird species by sampling site.

In the figure only the six most abundant bird species for each site are shown: Least

Sandpiper (LS), Yellow Warbler (YW), White Ibis (WI), Green Heron (GH), Great Egret (GE),

Tropical Kingbird (TK), Great-tailed Grackle (GG), Magnificent Frigatebird (MF), American

White pelican (AWP), Black-bellied Whistling Duck (BWD), Green Kingfisher (GK), and Roseate Spoonbill (RS). 


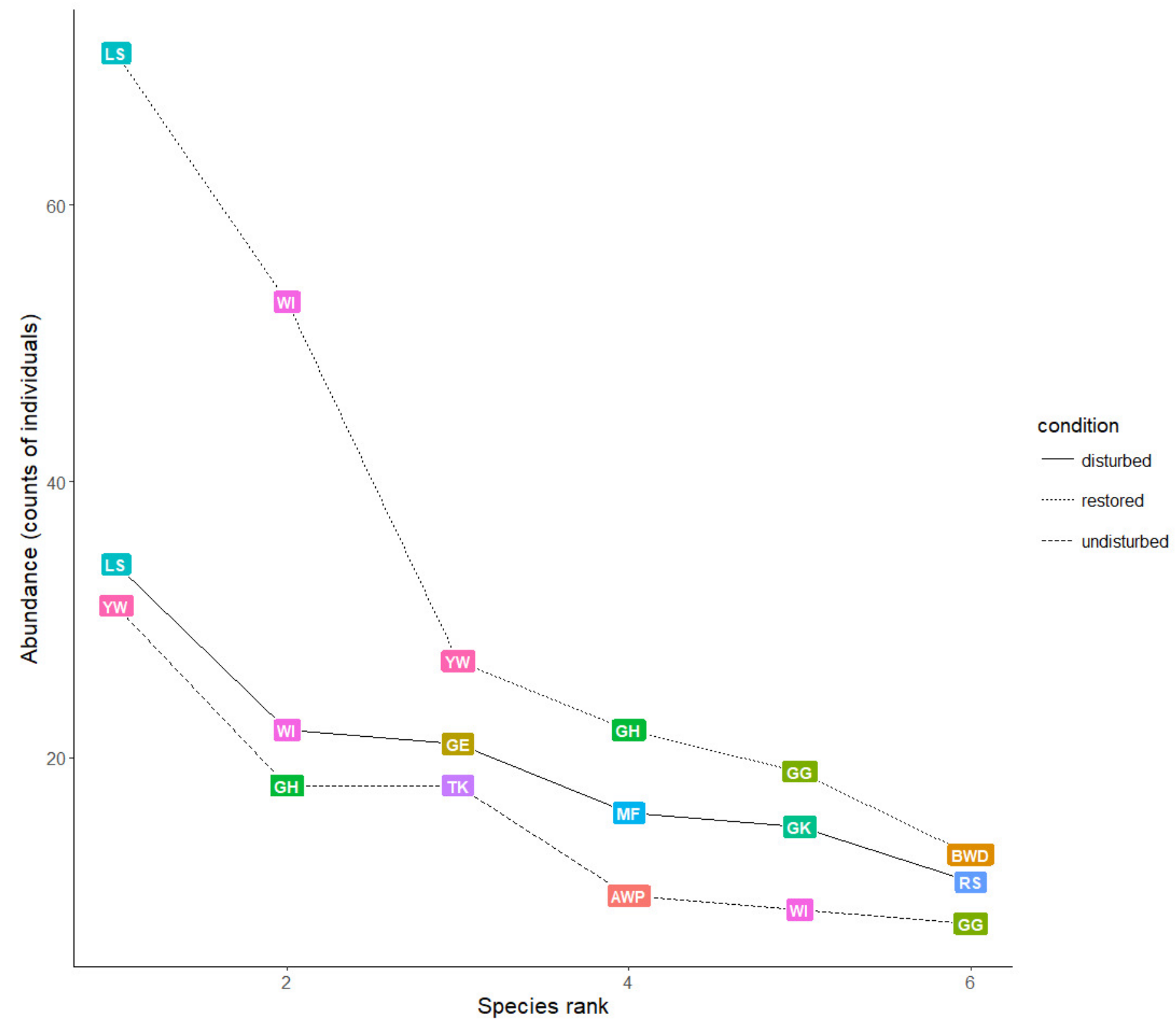


Figure 3

Abundance of bird functional groups by site.

In the restored site, the abundance of guilds such as macroinvertivores and insectivores increased as compared with the disturbed site.

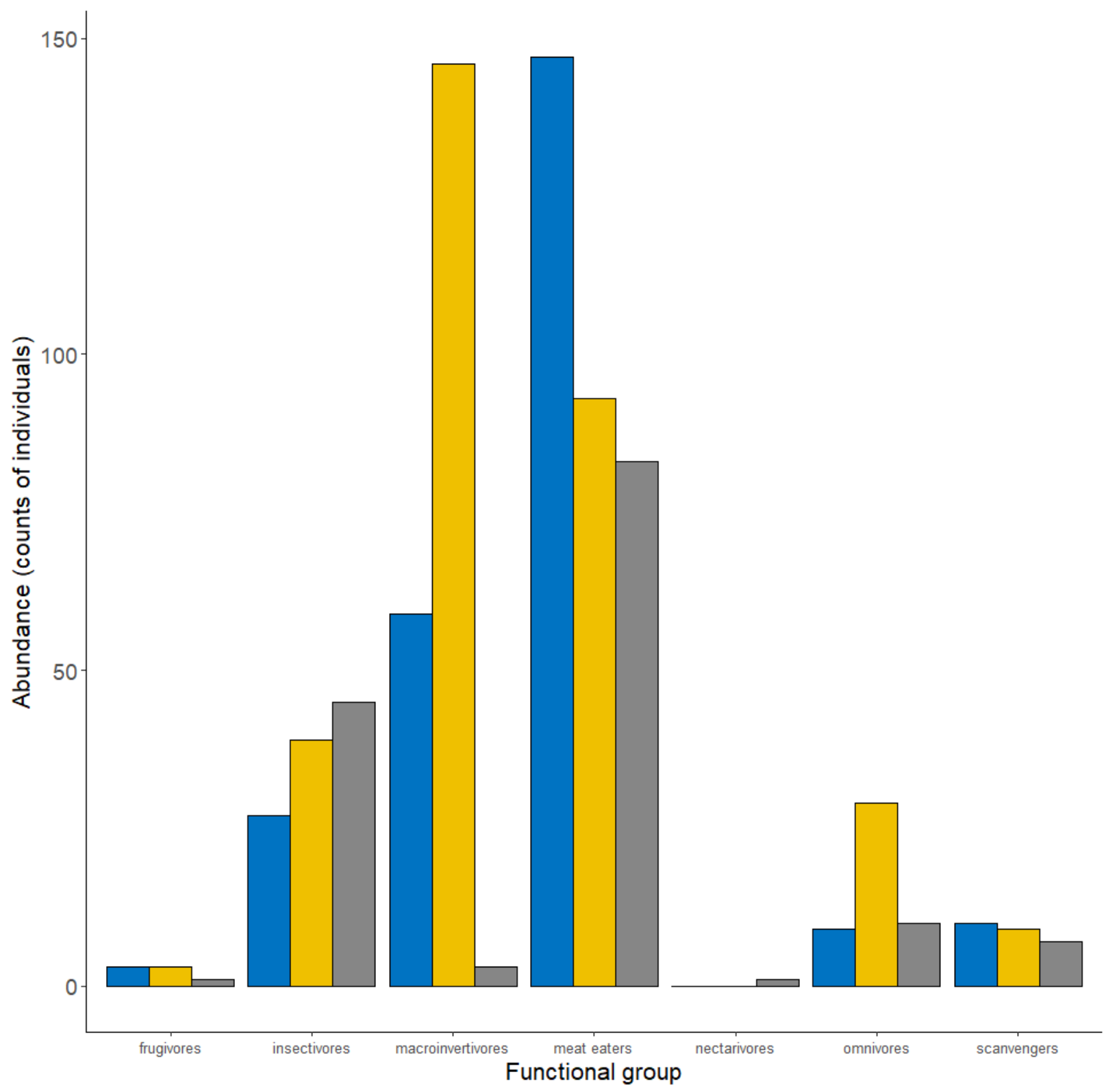

condition

disturbed

restored undisturbed 
Figure 4

The observed changes in porewater salinity though time at the restored site from the beginning to the end of the hydrological restoration (2011-2012), and two years later.

The horizontal lines in the boxes are medians, the open circles are the means, and whiskers are the minimum and maximum values.

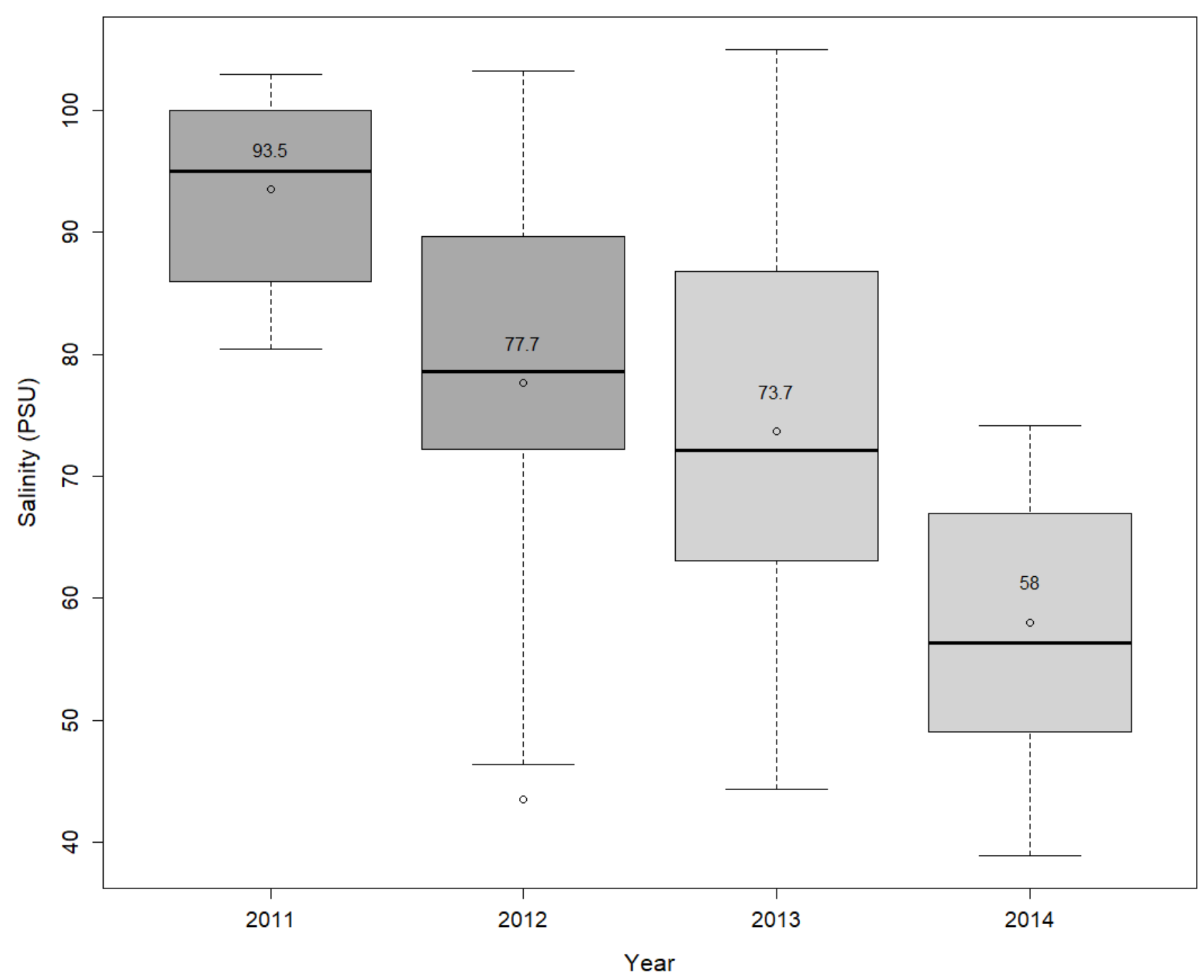




\section{Table $\mathbf{1}$ (on next page)}

Comparison of the mean values of hydroperiod, water-quality parameters and forest structure between studied areas following restoration at the restored site.

Only statistically significant results are shown. 


\begin{tabular}{|c|c|c|c|c|c|c|c|}
\hline Variable & Disturbed & Restored & Undisturbed & Test & $\mathrm{df}$ & $p$ & Post hoc \\
\hline $\begin{array}{l}\text { Flooding } \\
\text { frequency } \\
\text { (times/month) }\end{array}$ & 2.71 & 9.00 & 14.42 & $F=12.47$ & 2.00 & 0.003 & $\begin{array}{l}\mathrm{R}-\mathrm{D}=0.038 \\
\mathrm{U}-\mathrm{D}<0.001\end{array}$ \\
\hline $\begin{array}{l}\text { Flooding } \\
\text { duration (h) }\end{array}$ & 588.14 & 404.42 & 314.71 & $F=2.41$ & 2.00 & 0.118 & - \\
\hline $\begin{array}{l}\text { Tidal range } \\
\text { (m) }\end{array}$ & 0.09 & 0.09 & 0.05 & $F=2.25$ & 2.00 & 0.133 & - \\
\hline $\begin{array}{l}\text { Salinity } \\
\text { (PSU) }\end{array}$ & 34.93 & 34.12 & 33.28 & $\chi^{2}=10.25$ & 2.00 & 0.005 & $\mathrm{U}-\mathrm{D}=0.004$ \\
\hline $\mathrm{pH}$ & 8.15 & 8.11 & 8.02 & $F=12.32$ & 2.30 & 0.001 & $\begin{array}{l}\mathrm{U}-\mathrm{D}<0.001 \\
\mathrm{U}-\mathrm{R}=0.023\end{array}$ \\
\hline $\begin{array}{l}\text { Redox } \\
\text { potential }\end{array}$ & 82.09 & 91.18 & 85.18 & $\chi^{2}=3.42$ & 2.00 & 0.180 & - \\
\hline $\begin{array}{l}\text { Temperature } \\
\left({ }^{\circ} \mathrm{C}\right)\end{array}$ & 28.02 & 29.94 & 28.87 & $\chi^{2}=11.81$ & 2.00 & 0.002 & $\mathrm{R}-\mathrm{D}=0.001$ \\
\hline $\begin{array}{l}\text { Depth } \\
(\mathrm{cm})\end{array}$ & 54.62 & 74.96 & 117.54 & $F=31.87$ & 2.00 & $\begin{array}{c}< \\
0.001\end{array}$ & $\begin{array}{l}\mathrm{U}-\mathrm{D}<0.001 \\
\mathrm{U}-\mathrm{R}<0.001 \\
\mathrm{R}-\mathrm{D}=0.043\end{array}$ \\
\hline $\begin{array}{l}\text { No. of tree } \\
\text { species }\end{array}$ & 1.09 & 1.36 & 1.90 & $\chi^{2}=12.16$ & 2.00 & 0.002 & $\mathrm{U}-\mathrm{D}=0.008$ \\
\hline $\begin{array}{l}\text { Tree density } \\
\text { (trees/ha) }\end{array}$ & 345 & 763 & 709 & $\chi^{2}=6.45$ & 2.00 & 0.039 & $\mathrm{R}-\mathrm{D}=0.035$ \\
\hline $\begin{array}{l}\text { Basal area } \\
\left(\mathrm{m}^{2}\right)\end{array}$ & 1.29 & 4.31 & 7.02 & $\chi^{2}=15.39$ & 2.00 & $\begin{array}{c}< \\
0.001\end{array}$ & $\mathrm{U}-\mathrm{D}<0.001$ \\
\hline
\end{tabular}

1 Note: In Test column, $F$ is for ANOVA and $\chi^{2}$ is for Kruskal-Wallis rank sum test. In Post hoc

2 column, comparisons between pairs of sites $(\mathrm{R}=$ restored, $\mathrm{D}=$ degraded, $\mathrm{U}=$ undisturbed $)$, were

3 tested for significance using either HDS Tukey's or Nemenyi's tests. A dash means that the test

4 was not carried out for that variable. 


\section{Table 2 (on next page)}

Avian community diversity indexes at the study locations. 


\begin{tabular}{lcccccc}
\hline Habitat & $n$ & $\begin{array}{c}\text { Observed } \\
\text { richness }\end{array}$ & Mean \pm SD & $\begin{array}{c}\text { Expected } \\
\text { richness }\end{array}$ & 1-Simpson & $\begin{array}{c}\text { Berger } \\
\text { Parker }\end{array}$ \\
\hline Undisturbed & 11 & 28 & $5.27 \pm 2.28$ & 44.2 & 0.906 & 0.207 \\
Restored & 11 & 41 & $9.00 \pm 3.38$ & 46.3 & 0.893 & 0.230 \\
Disturbed & 11 & 41 & $9.36 \pm 2.20$ & 54.5 & 0.945 & 0.133 \\
\hline
\end{tabular}

1 Note: $n$ is the number of sampling points. 


\section{Table 3 (on next page)}

Results of the multivariate analysis (best fitted glm).

The greater the deviance, the stronger the effects of the environmental variables on the abundance of bird species (A) and the abundance of functional groups (B). 


\begin{tabular}{lcccc}
\hline & \multicolumn{2}{c}{ A } & \multicolumn{2}{c}{ B } \\
\hline Site feature & Deviance & $P$ & Deviance & $P$ \\
\hline Habitat condition & 162.50 & 0.012 & 22.598 & 0.110 \\
Water temperature & 113.29 & 0.001 & - & - \\
Redox & 82.83 & 0.029 & - & - \\
Water salinity & 71.86 & 0.040 & - & - \\
No. Tree species & 83.02 & 0.003 & 8.623 & 0.388 \\
Basal area & 82.33 & 0.023 & 6.053 & 0.605 \\
Tree density & 76.50 & 0.035 & 6.719 & 0.490 \\
Basal area : Tree density & 45.00 & 0.157 & - & - \\
Detectability & - & - & 17.780 & 0.019 \\
\hline
\end{tabular}

1

2 Note: Either dash is for variables not included in the models, or for models not reaching 3 convergence when including those variables. 


\section{Table 4 (on next page)}

Similarity analysis of species abundance among sites.

In A), the comparison of Undisturbed (UN) vs Restored (RS) is shown, B) Undisturbed vs Disturbed (DS), and C) Restored vs Disturbed. Species are ordered by their contribution according to the dissimilarity:standard deviation ratio (D/SD). 


\begin{tabular}{|c|c|c|c|c|}
\hline A) & $\begin{array}{l}\text { Av. dissin } \\
76.83 \\
\text { Av.Abund } \\
\text { UN }\end{array}$ & $\begin{array}{c}\text { milarity }= \\
\text { Av.Abund } \\
\text { RS }\end{array}$ & $\begin{array}{c}\text { Contribution } \\
(\%)\end{array}$ & $\mathrm{D} / \mathrm{SD}$ \\
\hline Yellow Warbler & 1.45 & 1.14 & 6.11 & 1.21 \\
\hline Green Heron & 0.89 & 1.08 & 7.35 & 1.12 \\
\hline White Ibis & 0.84 & 0.56 & 5.84 & 1.04 \\
\hline Double-crested Cormorant & 0.31 & 0.70 & 4.72 & 0.96 \\
\hline Tropical Kingbird & 0.61 & 0.09 & 3.72 & 0.89 \\
\hline Great-tailed Grackle & 0.26 & 0.88 & 6.32 & 0.65 \\
\hline Least Sandpiper & 0.09 & 1.14 & 5.55 & 0.58 \\
\hline \multirow[t]{2}{*}{ В) } & $\begin{array}{l}\text { Av. dissin } \\
80.93\end{array}$ & milarity $=$ & & \\
\hline & $\begin{array}{c}\text { Av.Abund } \\
\text { UN }\end{array}$ & $\begin{array}{c}\text { Av.Abund } \\
\text { DS } \\
\end{array}$ & $\begin{array}{c}\text { Contribution } \\
(\%)\end{array}$ & $\mathrm{D} / \mathrm{SD}$ \\
\hline Yellow Warbler & 1.45 & 0.79 & 6.3 & 1.30 \\
\hline Green Heron & 0.89 & 0.67 & 5.32 & 1.18 \\
\hline White Ibis & 0.84 & 1.03 & 6.32 & 1.15 \\
\hline Great Egret & 0.44 & 0.93 & 5.63 & 1.01 \\
\hline Tropical Kingbird & 0.61 & 0.27 & 3.52 & 1.01 \\
\hline Least Sandpiper & 0.09 & 1.19 & 6.68 & 0.95 \\
\hline \multirow[t]{2}{*}{ C) } & $\begin{array}{l}\text { Av. dissir } \\
75.41\end{array}$ & milarity $=$ & & \\
\hline & $\begin{array}{c}\text { Av.Abund } \\
\text { RS }\end{array}$ & $\begin{array}{c}\text { Av.Abund } \\
\text { DS } \\
\end{array}$ & $\begin{array}{c}\text { Contribution } \\
(\%)\end{array}$ & $\mathrm{D} / \mathrm{SD}$ \\
\hline Green Heron & 1.08 & 0.67 & 5.02 & 1.27 \\
\hline Yellow Warbler & 1.14 & 0.79 & 4.43 & 1.18 \\
\hline White Ibis & 0.56 & 1.03 & 4.90 & 1.08 \\
\hline Great Egret & 0.62 & 0.93 & 4.84 & 1.08 \\
\hline $\begin{array}{l}\text { Yellow-crowned } \\
\text { Heron }\end{array}$ & 0.49 & 0.63 & 3.59 & 1.07 \\
\hline Least Sandpiper & 1.14 & 1.19 & 8.23 & 1.05 \\
\hline Reddish Egret & 0.53 & 0.53 & 3.24 & 1.02 \\
\hline Double-crested Cormorant & 0.70 & 0.34 & 3.59 & 1.00 \\
\hline
\end{tabular}




\section{Table 5 (on next page)}

Indicator species index (IndVal) values for key species within each sampling site.

A percentage $>25 \%$ and a $p$-value $\leq 0.05$ mean that the selected species are good indicators for a given habitat condition. 


\begin{tabular}{lccc}
\hline Species & Habitat condition & IndVal (\%) & $p$ \\
\hline Tropical Kingbird & Undisturbed & 39 & 0.068 \\
Blue-winged Teal & Restored & 29 & 0.057 \\
Mangrove Swallow & Disturbed & 27 & 0.951 \\
\hline
\end{tabular}

1 